

\section{DISCLAIMER}

This report was prepared as an account of work sponsored by an agency of the United States Government. Neither the United States Government nor any agency Thereof, nor any of their employees, makes any warranty, express or implied, or assumes any legal liability or responsibility for the accuracy, completeness, or usefulness of any information, apparatus, product, or process disclosed, or represents that its use would not infringe privately owned rights. Reference herein to any specific commercial product, process, or service by trade name, trademark, manufacturer, or otherwise does not necessarily constitute or imply its endorsement, recommendation, or favoring by the United States Government or any agency thereof. The views and opinions of authors expressed herein do not necessarily state or reflect those of the United States Government or any agency thereof. 


\section{DISCLAIMER}

Portions of this document may be illegible in electronic image products. Images are produced from the best available original document. 
Distribution Category UC-77T

Engineering Physics and Mathematics Division

DOE/HTGR--86-062

TI87 025801

\section{APPLICATION OF ENDF DATA TO THE AVR REACTOR WITH HIGHLY ENRICHED URANIUM FUEL AND THORIUM FEED}
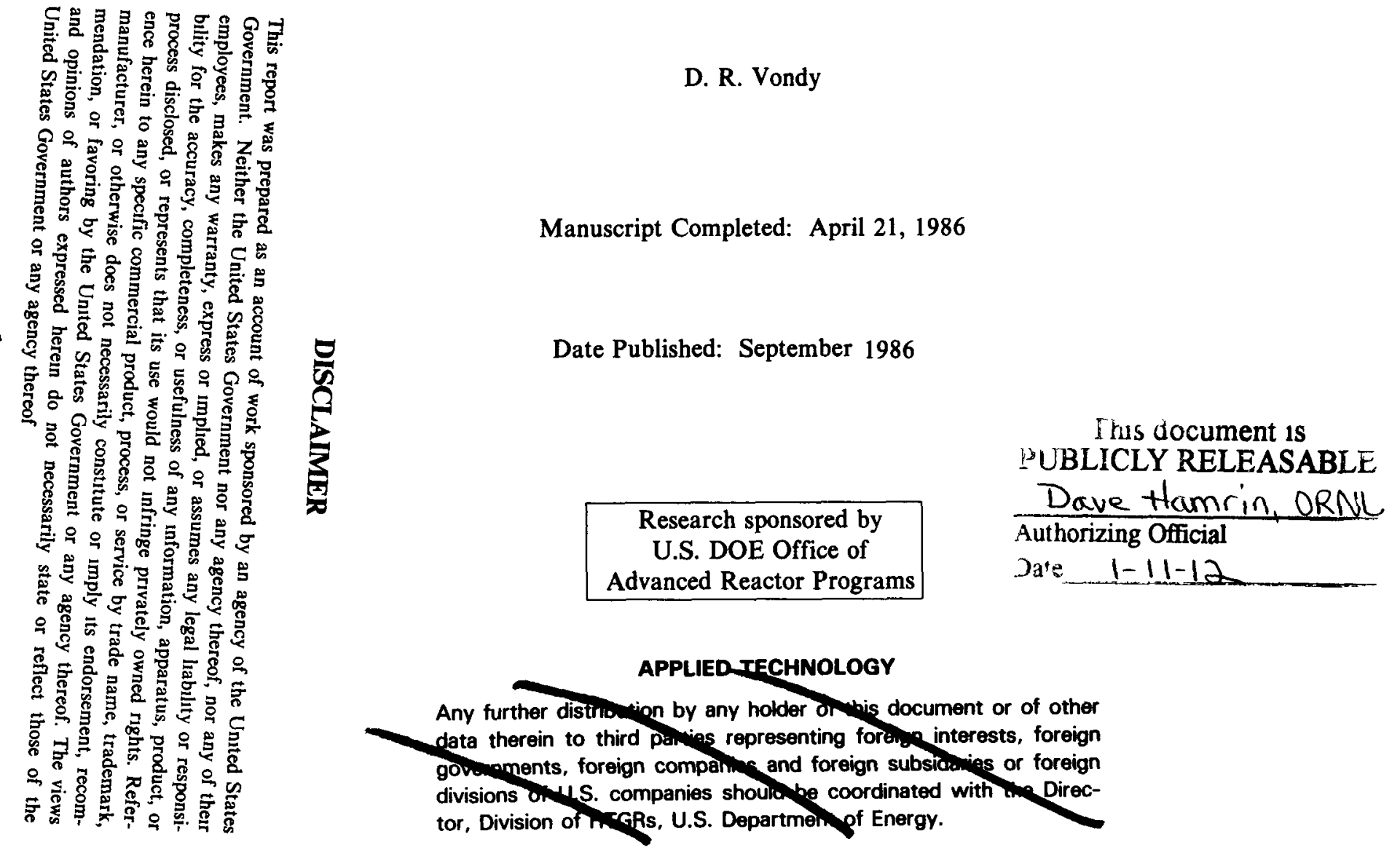

Prepared by the

OAK RIDGE NATIONAL LABORATORY

Oak Ridge, Tennessee 37831 operated by Martin Marietta Energy Systems, Inc. Under Contract No. DE-ACO5-84OR21400

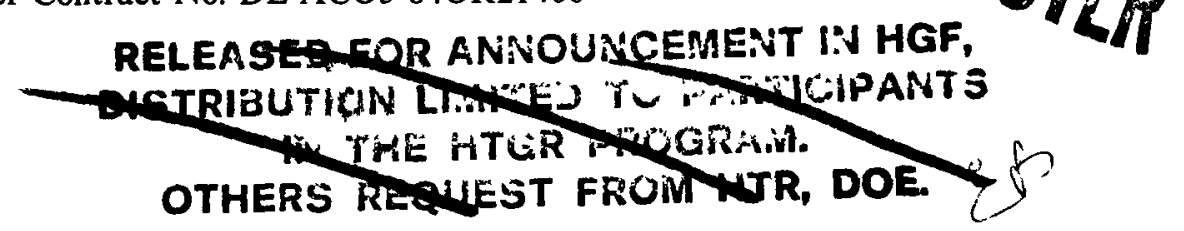


TABLE OF CONTENTS

TECHNOLOGY EXCHANGE

ABSTRACT

INTRODUCTION

CORE CHARACTERISTICS

TEMPERATURE COEFFICIENTS

SUPPLEMENTAL INFORMATION

CONTROL ROD WORTH

Exploratory Two-dimensional Results

9

Results for Control Rod Worth

ADDITIONAL REACTION RATE DATA

Regarding the Multiplication

ACKNOWLEDGEMENTS

14

REFERENCES

14

APPENDIX

METHODS

16

NUCLEAR DATA

16

CROSS SECTION PROCESSING

16

MODELING

18

18 


\title{
APPLICATION OF ENDF DATA TO THE AVR REACTOR WITH HIGHLY ENRICHED URANIUM FUEL AND THORIUM FEED
}

\author{
D. R. Vondy
}

\section{TECHNOLOGY EXCHANGE}

This report provides results of analyses performed within a cooperative project involving Oak Ridge National Laboratory (ORNL), Arbeitsgemeinschaft Versuchs Reaktor GmbH (AVR) and Kernforschungsanlage Jülich GmbH (KFA) in reactor physics, performance and safety. This project has been established within the frame of the HTR Implementing Agreement between the U.S. Department of Energy and the Ministry of Research and Technology of the Federal Republic of Germany.

\begin{abstract}
Calculations were done applying ENDF data to the German AVR pebble bed reactor at KFA. Several core models were used, and the results obtained with ORNL methods for the multiplication, reaction rates, temperature coefficient of reactivity, and fuel temperature distributions are reported and compared. Only a small difference in multiplication is found for this core in going from ENDF/B-IV to ENDF/B-V cross-section data. The temperature coefficients calculated with the ENDF/B-V are somewhat smaller in magnitude. The worth of control rods was obtained and only a small difference was found with the data, but the calculated results are high compared with experiment. Neutron reaction rates with the key actinides are reported for three-dimensional core calculations.
\end{abstract}




\section{INTRODUCTION}

Calculations were done for the AVR pebble bed reactor located at KFA in Germany. Figure 1 shows a vertical view of the core.

The two primary objectives of this effort were:

1. Comparing the nuclear behavior predicted with ENDF/B-V ${ }^{1}$ and with ENDF/V-IV ${ }^{2}$ data, and

2. Testing ORNL methods in use for analysis of high-temperature graphite-moderated reactor performance.

It should be noted that these ORNL methods have been implemented for rather general application, and no tailoring was done for this specific application which would be normally done if the reactor operation was being supported directly. In particular, the thermal hydraulics modeling could be improved. No bias was applied to effect a critical system as would be usual in analysis. Special representation of the voided region above the pebble bed was not done. Care should be taken to avoid absolute interpretation of these results. Thus that model producing a value of the multiplication factor nearest to unity may or may not be best. It will be interesting to compare these results with data from the operation and its supporting analysis effort.

A two-dimensional (R-Z) geometric core model was selected as a reference geometry to satisfy a number of requirements. It is similar to one in use at AVR. The ability to easily extend this description to a three-dimensional model was desirable for calculating control rod worths. Not only was a realistic representation of the detailed core contents desired, but the capability to extend the model to represent the flow of the pebbles for testing methods was of interest. The modeling was also influenced by the requirements for the thermal hydraulics in (RZ) geometry. Three cases were treated with different core contents but with essentially the same geometric arrangement:

1. AVR MODEL - the nuclide concentrations supplied by $\mathrm{AVR}^{3}$ for 100 core regions,

2. CORE-AVERAGE - a simple average of the core contents from AVR, ${ }^{4}$ and

3. CALCULATED - nuclide concentrations were obtained by calculation applying the steady-state continuous-fueling model $^{5}$ for the geometry modeling pebble flow, the results depending on the nuclear data in use. Information about the details of the control over the fresh pebble feed and the recycling were not available leaving the accuracy of this modeling somewhat uncertain.

Additional information about the application of methods, modeling and the nuclear data processing is included in the Appendix.

In some cases results are reported that are subject to interpretation or have large uncertainties and these are shown in parentheses. $1.5+13$ equals $1.5 \times 10^{13}$.

Values for the temperature coefficients were calculated from results for two states often involving rather large temperature differences using the equation

$$
\frac{T \partial k}{k \partial T}=\frac{\ln \left(k_{2} / k_{1}\right)}{\ln \left(T_{2} / T_{1}\right)}
$$




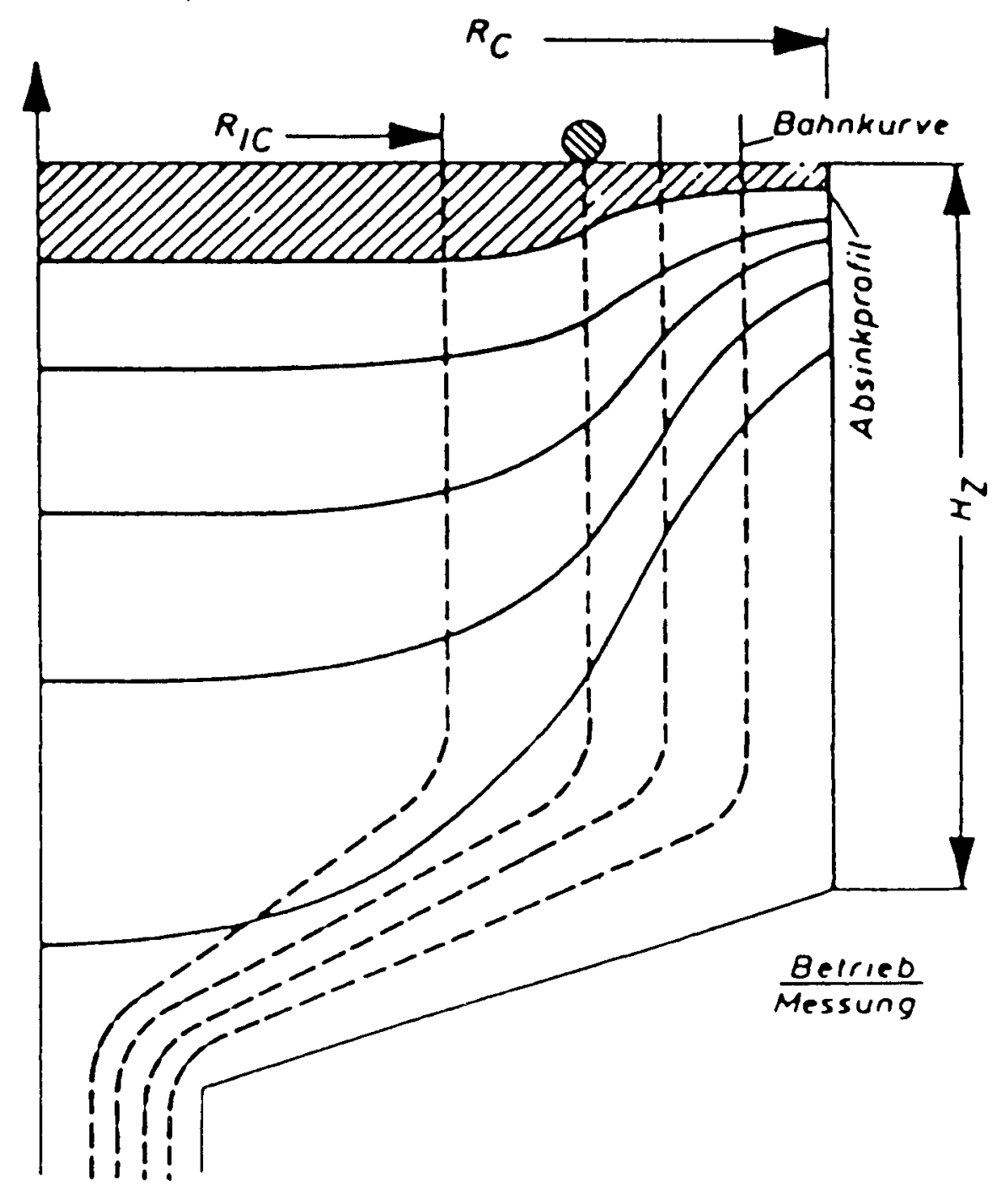

a) Gemessene Bahnkurven und

Absinkprofile

Fig. 1. AVR elevation indicating pebble residence. 
and values are simply reported at the average temperature between $T_{1}$ and $T_{2}$. Reactivity changes, as for control rod worth, are calculated as $\Delta k / k=\ln \left(k_{2} / k_{1}\right)$.

Extension of these results to address specific aspects would be possible. Such information as temperature distributions is not practical to include in this short report form, but such data can be made available.

\section{CORE CHARACTERISTICS}

Primary calculations were done in (RZ) geometry for $46 \mathrm{MW}(\mathrm{t})$. An initial test was done to indicate the effect of homogenization of the graphite noses that project inward from the radial refelector to hold the control rods. A $(\theta \mathrm{R})$ model set up to explore control rod modeling yielded a $k$ of 0.94205 compared with 0.97091 for a one-dimensional (R) geometry model that is similiar to the $(\mathrm{RZ})$ cases. This indicates a lower effectiveness of the graphite noses than will be realized with homogenization in the (RZ) models.

The two-dimensional core results obtained by applying the three models and two sets of nuclear data are shown in Table 1 for the reference fuel and an average core graphite temperature of $800^{\circ} \mathrm{K}$. Inventories of key materials are shown at the bottom of the table for comparison. A small decrease in the multiplication factor of this core is found in going from ENDF/B-IV data to ENDF/B-V. Data obtained in the FRG ${ }^{4}$ with a recent model are shown in the table for comparison. The current results seem to lack about 0.02 absorption fraction in the fission products for the AVR model in comparison with FRG results, the multiplication is high by a contribution of 0.02 or more from the two-dimensional model, and the effective temperature used is a bit low increasing multiplication.

The geometric representation for the continuous fueling model tends to overestimate the multiplication so the fissile inventory is low for the critical state. The core content of ${ }^{238} \mathrm{U}$ is considerably lower for this model and the chosen feed enrichment than shown in the German data. The calculated external fissile feed rate was 47.3 grams/day $\left({ }^{235} \mathrm{U}\right)$ or 0.788 grams per fresh pebble with ENDF/B-V data, and the discharge rate 10.9 grams/day fissile.

Thermal hydraulics results are shown in Table 2 for the cases discussed above. Note that trivial differences are found in the fuel temperatures for the different nuclear data, but effects of different modeling are quite significant. The model that distributes average core contents over the core results in extreme elevated temperatures.

\section{TEMPERATURE COEFFICIENTS}

The nuclear data were processed at core temperatures of $400,800,1200$, and 1600 or $2000^{\circ} \mathrm{K}$ to generate information about the temperature coeffcicient of reactivity. These calculations were made for gross effects in the core including the effects of temperature on the resonance shielding, thermal spectrum, and leakage. A more negative temperature coefficient of reactivity is associated with raising the temperature in more and more of the graphite in the core. The most positive value (lowest in magnitude) of the coefficient is associated with an increase in only the kernel temperature, the graphite remaining unheated. Here the temperature change is assumed to occur without concern about how this might come about. The core temperature was held at $800^{\circ} \mathrm{K}$ except when it was varied, and the reflector was held at $600^{\circ} \mathrm{K}$. 
Table 1. AVR core characteristics

\begin{tabular}{|c|c|c|c|c|c|c|c|}
\hline \multirow{2}{*}{$\begin{array}{l}\text { Cross sections } \\
\text { Nuclide data }\end{array}$} & \multicolumn{3}{|c|}{ ENDF/B-IV } & \multicolumn{3}{|c|}{ ENDF/B-V } & \multirow{2}{*}{$\begin{array}{c}\text { (FRG) } \\
\text { AVR model }\end{array}$} \\
\hline & AVR model & Core-average & Calculated & AVR model & Core-average & Calculated & \\
\hline Multiplication & 1.04666 & 1.03364 & 1.0 & 1.04646 & 1.03276 & 1.0 & \\
\hline \multicolumn{8}{|l|}{ Fissile conversion ratio } \\
\hline Calculated & 0.3186 & 0.3345 & 0.3705 & 0.3258 & 0.3424 & 0.3782 & \\
\hline Critical & $(0.4103)$ & $(0.4013)$ & 0.3705 & $(0.4176)$ & $(0.4078)$ & 0.3782 & \\
\hline \multicolumn{8}{|c|}{ Peak power density $\left(w / \mathrm{cm}^{3}\right)$} \\
\hline Core & 4.006 & 3.663 & 3.598 & 3.994 & 3.653 & 3.625 & \\
\hline Pebble & - & - & 10.76 & • & - & 10.52 & \\
\hline \multicolumn{8}{|c|}{ Peak fast flux $\left(>8 \times 10^{5} \mathrm{cV}, \mathrm{n} / \mathrm{cm}^{2}-8\right)$} \\
\hline Core & $4.53+13$ & $6.36+13$ & $6.37+13$ & $4.53+13$ & $6.34+13$ & $6.40+13$ & \\
\hline Rad. reflector & $1.86+13$ & $1.53+13$ & $1.62+13$ & $1.85+13$ & $1.53+13$ & $1.62+13$ & \\
\hline \multicolumn{8}{|l|}{ Fraction Abeorption } \\
\hline${ }^{212}$ Th & 0.1378 & 0.1429 & 0.1734 & 0.1400 & 0.1453 & 0.1759 & 0.1575 \\
\hline${ }^{23} \mathrm{~Pa}$ & 0.0015 & 0.0016 & 0.0025 & 0.0015 & 0.0016 & 0.0026 & 0.0016 \\
\hline${ }^{233} \mathrm{U}$ & 0.0986 & 0.0945 & 0.1077 & 0.0990 & 0.0949 & 0.1097 & 0.1063 \\
\hline${ }^{204} U$ & 0.0048 & 0.0048 & 0.0027 & 0.0051 & 0.0052 & 0.0030 & 0.0056 \\
\hline${ }^{23} \mathrm{U}$ & 0.3988 & 0.3977 & 0.3720 & 0.3952 & 0.3940 & 0.3665 & 0.4157 \\
\hline${ }^{26} U$ & 0.0074 & 0.0076 & 0.0063 & 0.0075 & 0.0077 & 0.0063 & 0.0087 \\
\hline${ }^{20} \mathrm{U}$ & 0.0171 & 0.0182 & 0.0033 & 0.0171 & 0.0183 & 0.0032 & 0.0073 \\
\hline${ }^{29} \mathrm{Pu}$ & 0.0058 & 0.0061 & 0.0029 & 0.0058 & 0.0062 & 0.0029 & 0.0071 \\
\hline${ }^{200} \mathrm{Pu}$ & 0.0026 & 0.0026 & 0.0009 & 0.0026 & 0.0027 & 0.0009 & 0.0027 \\
\hline${ }^{201} \mathrm{Pu}$ & 0.0021 & 0.0022 & 0.0007 & 0.0022 & 0.0023 & 0.0008 & 0.0025 \\
\hline${ }^{24} \mathrm{Pu}$ & 0.0002 & 0.0002 & - & 0.0002 & 0.0002 & - & 0.0002 \\
\hline${ }^{203} \mathrm{Am}$ & 0 & 0 & - & 0 & 0 & - & - \\
\hline Fission Products & 0.0847 & 0.1046 & 0.0847 & 0.0835 & 0.1040 & 0.0834 & 0.1037 \\
\hline \multicolumn{8}{|l|}{ Inventory (kg) } \\
\hline${ }^{232} \mathrm{Th}$ & 515.1 & 524.9 & 578.0 & & 577.7 & 551.5 & \\
\hline${ }^{233} \mathrm{U}$ & 7.32 & 7.30 & 7.13 & & & 7.22 & 7.81 \\
\hline${ }^{23} \mathrm{U}$ & 31.40 & 31.49 & 25.46 & & & 25.26 & 33.18 \\
\hline${ }^{204} U$ & 27.75 & 30.24 & 5.17 & & 5.13 & 31.54 & \\
\hline Fissile (including ${ }^{23} \mathrm{~Pa}$ ) & 39.40 & 39.54 & 33.40 & & 33.31 & 41.76 & \\
\hline
\end{tabular}


Table 2. AVR thermal hydraulics results

\begin{tabular}{|c|c|c|c|c|c|c|c|}
\hline \multicolumn{2}{|c|}{ Cross sections } & \multicolumn{3}{|c|}{ ENDF/B-IV } & \multicolumn{3}{|c|}{ ENDF/B-V } \\
\hline Nuclide data & & AVR model & Core-average & Calculated & AVR model & Core-average & Calculated \\
\hline \multicolumn{8}{|c|}{ Outlet coolant temperature $850^{\circ} \mathrm{C}$, inlet $265^{\circ} \mathrm{C}$} \\
\hline Bed pressure drop (ATM) & & 0.0499 & 0.0542 & 0.0520 & 0.0499 & 0.0542 & 0.0520 \\
\hline \multicolumn{8}{|l|}{ Temperatures $\left({ }^{\circ} \mathrm{C}\right)$} \\
\hline Peak coolant outlet & & 944. & 1184. & 1142 & 943. & 1183. & 1137. \\
\hline Mean fuel & & 632. & 662. & 633. & 632. & 662. & 633. \\
\hline Effective fuel ${ }^{a}$ & & 645. & 654. & 651. & 645. & 654. & 650. \\
\hline Peak fuel & & 1011. & 1232. & 1234. & 1010. & 1230. & 1227. \\
\hline \multirow[t]{9}{*}{ Fraction fuel } & $>1200^{\circ} \mathrm{C}$ & & 0.0011 & 0.0003 & & 0.0011 & 0.0003 \\
\hline & $>1150$ & & 0.0032 & 0.0025 & & 0.0031 & 0.0022 \\
\hline & $>1100$ & & 0.0068 & 0.0061 & & 0.0067 & 0.0058 \\
\hline & $>1050$ & & 0.0114 & 0.0123 & & 0.0113 & 0.0118 \\
\hline & $>1000$ & 0.0025 & 0.0168 & 0.0258 & 0.0024 & 0.0167 & 0.0254 \\
\hline & $>950$ & 0.0598 & 0.0249 & 0.0513 & 0.0597 & 0.0247 & 0.0509 \\
\hline & $>900$ & 0.127 & 0.0374 & 0.0898 & 0.126 & 0.0373 & 0.0895 \\
\hline & $>850$ & 0.192 & 0.0507 & 0.136 & 0.192 & 0.0506 & 0.136 \\
\hline & $>800$ & 0.253 & 0.0748 & 0.198 & 0.253 & 0.0747 & 0.198 \\
\hline \multicolumn{8}{|c|}{ Outlet coolant temperature $950^{\circ} \mathrm{C}$, inlet $265^{\circ} \mathrm{C}$} \\
\hline Bed pressure drop (ATM) & & 0.0396 & 0.0417 & 0.0408 & 0.0396 & 0.0417 & 0.0420 \\
\hline \multicolumn{8}{|l|}{ Temperatures $\left({ }^{\circ} \mathrm{C}\right)$} \\
\hline Peak coolant outlet & & 1058. & 1323. & 1299. & 1058. & 1352. & 1295. \\
\hline Mean fuel & & 687. & 723. & 690. & 687. & 723. & 690. \\
\hline Effective fuel ${ }^{a}$ & & 701. & 713. & 710. & 701. & 713. & 709. \\
\hline Peak fuel & & 1123. & 1397. & 1393. & 1122. & 1398. & 1387. \\
\hline \multirow[t]{11}{*}{ Fraction fuel } & $>1300^{\circ} \mathrm{C}$ & & & 0.0024 & & & 0.0022 \\
\hline & $>1250$ & & 0.0063 & 0.0055 & & 0.0064 & 0.0053 \\
\hline & $>1200$ & & 0.0098 & 0.0100 & & 0.0098 & 0.0097 \\
\hline & $>1150$ & & 0.0143 & 0.0187 & & 0.0144 & 0.0185 \\
\hline & $>1100$ & 0.0115 & 0.0189 & 0.0337 & 0.0114 & 0.0190 & 0.0336 \\
\hline & $>1050$ & 0.0668 & 0.0272 & 0.0592 & 0.0667 & 0.0273 & 0.0592 \\
\hline & $>1000$ & 0.124 & 0.0381 & 0.0928 & 0.124 & 0.0381 & 0.0929 \\
\hline & $>950$ & 0.181 & 0.0493 & 0.131 & 0.181 & 0.0493 & 0.131 \\
\hline & $>900$ & 0.232 & 0.0667 & 0.180 & 0.232 & 0.0666 & 0.180 \\
\hline & $>850$ & 0.288 & 0.0981 & 0.244 & 0.287 & 0.0975 & 0.245 \\
\hline & $>800$ & 0.345 & 0.221 & 0.315 & 0.345 & 0.221 & 0.316 \\
\hline
\end{tabular}

${ }^{a}$ Power density weighted. 
Auxiliary one-dimensional core traverses were done applying 28 groups with discrete ordinates or 4-group diffusion theory using collapsed data from the discrete ordinates cases. An axial leakage (buckling) component was included. Multiplication values obtained for a temperature change of the whole fuel element using ENDF/B-V data are shown here using two diffusion models (A) and (B),

\begin{tabular}{|c|c|c|c|}
\hline \multirow{3}{*}{$\begin{array}{c}\text { Temperature } \\
\left({ }^{\circ} \mathbf{K}\right)\end{array}$} & \multicolumn{3}{|c|}{ Multiplication } \\
\hline & \multirow{2}{*}{$\begin{array}{l}\text { Discrete } \\
\text { ordinates }\end{array}$} & \multicolumn{2}{|c|}{ Diffusion } \\
\hline & & (A) & (B) \\
\hline 400 & 1.05847 & 1.08923 & 1.01719 \\
\hline 800 & 1.01361 & 1.04392 & 0.97091 \\
\hline 1200 & 0.99342 & 1.01880 & 0.94443 \\
\hline 1600 & 0.97482 & 0.99544 & 0.91978 \\
\hline
\end{tabular}

A primary cause for $k$ to be higher in the diffusion (A) cases than the discrete ordinates cases has not been identified. One difference of the (B) from the (A) cases was the use of a larger axial buckling term. These results lead to the following values of $T \partial k / k \partial T$,

\begin{tabular}{|c|c|c|c|}
\hline \multirow{3}{*}{$\begin{array}{c}\text { Temperature } \\
\left({ }^{\circ} \mathbf{K}\right)\end{array}$} & \multicolumn{3}{|c|}{ Coefficient } \\
\hline & \multirow{2}{*}{$\begin{array}{c}\text { Discrete } \\
\text { ordinates }\end{array}$} & \multicolumn{2}{|c|}{ Diffusion } \\
\hline & & (A) & (B) \\
\hline 600 & -0.0625 & -0.0613 & -0.0684 \\
\hline 1000 & -0.0496 & -0.0601 & -0.0682 \\
\hline 1400 & -0.0657 & -0.0806 & -0.0919 \\
\hline
\end{tabular}

The average of all of these values is -0.0676 .

Comparable values from discrete ordinates cases using ENDF/B-IV data are -0.0558 at $600^{\circ} \mathrm{K}$ and -0.0512 at $1000^{\circ} \mathrm{K}$. (The $1600^{\circ} \mathrm{K}$ processed ENDF/B-IV data seems to be bad.)

Partial heating of the fuel elements was also considered, namely heating of only the kernel (fueled particles) or of the inner fueled part of the pebbles. ENDF/B-V results are shown below [discrete ordinate and diffusion (A) results were averaged],

\begin{tabular}{lcccccc} 
& \multicolumn{3}{c}{$T \partial k / k \partial T$} & \multicolumn{3}{c}{$\partial k / k \partial T \times 10^{5}\left({ }^{\circ} \mathrm{C}^{-1}\right)$} \\
\cline { 2 - 7 } \multicolumn{1}{c}{$\begin{array}{c}\text { Portion } \\
\text { heated }\end{array}$} & $600^{\circ} \mathrm{K}$ & $1000^{\circ} \mathrm{K}$ & $1400^{\circ} \mathrm{K}$ & $600^{\circ} \mathrm{K}$ & $1000^{\circ} \mathrm{K}$ & $1400^{\circ} \mathrm{K}$ \\
\hline Kernel only & -0.0135 & -0.0140 & -0.0138 & -2.25 & -1.40 & -1.00 \\
Fueled part & -0.0318 & -0.0383 & -0.0491 & -5.30 & -3.83 & -3.51 \\
Whole pebble & -0.0619 & -0.0548 & -0.0732 & -10.3 & -5.48 & -5.22 \\
\hline
\end{tabular}


Note that heating of the graphite contributes considerably to the temperature coefficient.

Information about the temperature coefficient that was obtained from two-dimensional (RZ) diffusion theory calculations for a temperature rise of the whole fuel element is shown in Table 3. Note that the ENDF/B-V data produces coefficients that are lower in magnitude.

Table 3. Temperature coefficient informatione

\begin{tabular}{|c|c|c|c|c|c|c|}
\hline \multirow{2}{*}{$\begin{array}{l}\text { Cross sections } \\
\text { Nuclide data }\end{array}$} & \multicolumn{3}{|c|}{ ENDF/B-IV } & \multicolumn{2}{|c|}{ ENDF/B-V } & \multirow[b]{2}{*}{ Calculated } \\
\hline & AVR model & Core-average & Calculated & AVR model & Core-average & \\
\hline \multicolumn{7}{|c|}{ Multiplication at temperature $\left({ }^{\circ} \mathbf{K}\right)$} \\
\hline 400 & 1.09788 & 1.08640 & 1.05117 & 1.09285 & 1.07486 & 1.04414 \\
\hline 800 & 1.04666 & 1.03365 & 1.0 & 1.04645 & 1.03276 & 1.0 \\
\hline 1200 & 1.01145 & 0.99783 & 0.96502 & 1.01800 & 1.01098 & 0.97346 \\
\hline 1600 & - & - & - & 0.99228 & 0.99126 & 0.94875 \\
\hline 2000 & 0.95217 & 0.93835 & 0.90324 & 0.96816 & 0.97203 & 0.92544 \\
\hline \multicolumn{7}{|c|}{ Coefficient $T \partial k / k \partial T$ at temperature $\left({ }^{\circ} \mathrm{K}\right)$, total } \\
\hline 600 & -0.0689 & -0.0714 & -0.0720 & -0.0626 & -0.0576 & -0.0623 \\
\hline 1000 & -0.0844 & -0.0870 & -0.0878 & -0.0680 & -0.0526 & -0.0663 \\
\hline 1400 & - & - & - & -0.0890 & -0.0685 & -0.0894 \\
\hline 1600 & -0.1182 & -0.1203 & -0.1295 & -0.0983 & -0.0769 & -0.0990 \\
\hline 1800 & - & - & - & -0.1102 & -0.0878 & -0.1115 \\
\hline \multicolumn{7}{|c|}{ Coefficient $\partial k / k \partial T \times 10^{5}{ }^{\circ} \mathrm{C}^{-1}$ at temperature $\left({ }^{\circ} \mathrm{K}\right)$, total } \\
\hline 600 & -11.48 & -11.90 & -12.00 & -10.43 & -9.61 & -10.38 \\
\hline 1000 & -8.44 & -8.70 & -8.78 & -6.80 & -5.26 & -6.63 \\
\hline 1400 & - & - & - & -6.35 & -4.89 & -6.38 \\
\hline 1600 & -7.39 & -7.52 & -8.09 & -6.14 & -4.81 & -6.19 \\
\hline 1800 & - & - & - & -6.12 & -4.88 & -6.19 \\
\hline
\end{tabular}

${ }^{a}$ Lacking good ENDF/B-IV data at $1600^{\circ} \mathrm{K}$, cases were run at $2000^{\circ} \mathrm{K}$ and the coefficients determined from 1200 and $2000^{\circ} \mathrm{K}$ data appropriate to $1600^{\circ} \mathrm{K}$ for comparison.

For comparison with these results, values calculated at the AVR for $\partial k / k \partial \mathrm{T}$ are $-5.94 \times 10^{-5}$ ${ }^{\circ} \mathrm{C}^{-1}$ at a coolant outlet temperature of $850^{\circ} \mathrm{C}$ and $-5.60 \times 10^{-5}$ at $950^{\circ} \mathrm{C}$ outlet temperature. ${ }^{4}$

\section{SUPPLEMENTAL INFORMATION}

The core calculation with the steady-state continuous-fueling model was also done using the calculated fuel temperature distributions and a simple linear interpolation of nuclear data between that for $400^{\circ} \mathrm{K}$ and for $1200^{\circ} \mathrm{K}$. Results for a $20 \%$ power level increase are shown in Table 4 based on a reference outlet coolant temperature of $850^{\circ} \mathrm{C}$. Conditions are shown without and with an associated increase in the coolant flow rate. These results are for a stabilized flow condition, not instantaneous. The results for a power level increase were also obtained with an available arctangent fit to the same two ENDF/B-V cross section sets. The reference $k$ was 1.00559 , and a bit smaller coefficients $P \partial k / k \partial P$ were obtained: -0.0295 with fixed coolant flow and -0.00172 with the coolant flow increased. 
Table 4. Results obtained for a $20 \%$ power level increase

\begin{tabular}{lcccc}
\hline \multicolumn{1}{c}{ Data } & ENDF/B-IV & & ENDF/B-V \\
\hline \multicolumn{1}{c}{ State } & $k$ & $P \partial k / k \partial P$ & $k$ & $P \partial k / k \partial P$ \\
\hline $\begin{array}{l}\text { Reference } \\
\text { Elevated power, fixed } \\
\text { coolant flow }\end{array}$ & 1.00829 & - & 1.00722 & - \\
$\begin{array}{l}\text { Elevated power, coolant flow } \\
\text { proportionally increased }\end{array}$ & 1.00116 & -0.0389 & 1.00143 & -0.0316 \\
\hline
\end{tabular}

\section{CONTROL ROD WORTH}

Calculations were done for highly enriched uranium fuel with thorium to estimate the reactivity worth of the insertion of the four control rods. The AVR MODEL nuclide concentrations were used for the three-dimensional calculations. Certain preliminary calculations were first done in $(\theta \mathrm{R})$ geometry to study the modeling. In these calculations 0.1 was added to the diffusion coefficients in the core to simulate streaming in the voids.

\section{Exploratory Two-dimensional Results}

The model is a one-eight core $(\theta \mathrm{R})$ traverse simulating the conditions of full removal or insertion of all four 8.4-cm diameter rods. The CORE-AVERAGE nuclide concentrations were used and the four-group cross sections came from ENDF/B-V data at a reference temperature of $800^{\circ}$ $\mathrm{K}$ except where shown otherwise.

Consider that the surface area per unit length of an $8.4 \mathrm{~cm}$ diameter control rod is $\pi \mathrm{D}=8.4 \pi$ $=26.39 \mathrm{~cm}^{2}$. Modeling this with a $10 \times 10$ meshpoint grid in $(\theta \mathrm{R})$ geometry yields the following effective surface areas for a black neutron absorber at thermal energy,

\begin{tabular}{|c|c|c|c|}
\hline Radial Dimension $(\mathrm{cm})$ & 6.0 & 7.0 & 8.0 \\
\hline \multicolumn{4}{|l|}{ Radians } \\
\hline 0.064 & 24.8 & 26.8 & 28.8 \\
\hline 0.072 & 26.4 & 28.4 & 30.4 \\
\hline 0.080 & 28.0 & 30.0 & 32.0 \\
\hline
\end{tabular}


Test calculations were done in $(\theta R)$ geometry to show the effect on the rod worth of varying these dimensions. Results obtained for $\partial k / k$ for rod insertion are

\begin{tabular}{|c|c|c|c|}
\hline Radial Dimension (cm) & 6.0 & 7.0 & 8.0 \\
\hline \multicolumn{4}{|l|}{ Radians } \\
\hline 0.064 & -0.0708 & -0.0720 & -0.0732 \\
\hline 0.072 & -0.0717 & -0.0726 & -0.0734 \\
\hline 0.080 & -0.0726 & -0.0730 & -0.0736 \\
\hline
\end{tabular}

These results indicate that due to a high thermal flux suppression, there is but a modest dependence of the results on the discrete representation. Note that increasing the rod size also increases the volume increasing epithermal absorptions. A $7.0-\mathrm{cm}$ radial dimension and 0.072 radians were used for the discrete representation in three dimensions.

Of interest was the consequence of a coarse representation in the fueled core along the $\theta$ coordinate. The high cost of obtaining three-dimensional problem solutions prompts the use of as few meshpoints as necessary. Test calculations produced the following results in $(\theta \mathrm{R})$ geometry,

\begin{tabular}{clcc}
$\begin{array}{c}\text { Fueled } \\
\text { Meshpoints }\end{array}$ & $\begin{array}{c}\text { Radians } \\
\text { Per Point }\end{array}$ & $\begin{array}{c}\text { Rods Out } \\
k\end{array}$ & $\begin{array}{c}\text { Rod Worth } \\
(\partial k / k)\end{array}$ \\
\hline 5 & 0.115 & 0.94508 & -0.0723 \\
7 & 0.082143 & 0.94517 & -0.0725 \\
10 & 0.0575 & 0.94525 & -0.0726 \\
15 & 0.038333 & 0.94522 & -0.0725 \\
\hline
\end{tabular}

A significant effect was not found, and eight points were used in the three-dimensional model.

A calculation was done to check the magnitude of the error from a discrete arrangement of meshpoints. A reference case was rerun doubling the numbers of meshpoints along each coordinate. Note that this was done to reveal the discretization error, and was not an attempt to test the representation of the control rod. The resulting multiplication for the rods out state was slightly higher and the control rod insertion worth was just under $1 \%$ larger in magnitude.

Calculations at three temperatures produced the following results,

\begin{tabular}{lccr} 
Core temperature $\left({ }^{\circ} \mathrm{K}\right)$ & 400 & 800 & 1200 \\
\hline & & & \\
$k$, rods out & 0.99105 & 0.94525 & 0.91960 \\
$k$, rods inserted & 0.92727 & 0.87910 & 0.85210 \\
$\Delta k / k$ rod insertion & -0.0665 & -0.0726 & -0.0762 \\
\hline
\end{tabular}

It is noted that these results show an increase in the control rod worth with increase in temperature. This infers an increase in the amount of reactivity associated with temperature change when the rods are inserted compared to the situation with them out. 
The $\mathrm{U}^{235}$ concentration was increased $25 \%$ yielding the following results,

\begin{tabular}{lccl}
\hline $\begin{array}{l}\text { Core Temperature }\left({ }^{\circ} \mathrm{K}\right) \\
\text { Multiplication }\end{array}$ & 400 & 800 & 1200 \\
$\quad$ Rods Out & 1.05136 & 1.00607 & 0.98031 \\
$\quad$ Rods In & 0.98800 & 0.94004 & 0.91277 \\
$\Delta k / k$ & -0.0622 & -0.0679 & 0.0714 \\
\hline
\end{tabular}

These are somewhat lower. It appears very desirable to represent the actual contents of the reactor and a desired range of applicability in multiplication.

There was some concern about modeling epithermal absorptions by the control rods. Cross sections were not made available for all of the materials. Test calculations were done varying the $B^{10}$ concentration. Note that effects in the thermal range are not affected directly by this since a black absorber rod surface condition was used. The following results were obtained relative to a rods out condition of $k=0.94520$, where the concentration is for smearing over the discrete area,

\begin{tabular}{lcc}
$\begin{array}{c}\mathrm{B}^{10} \\
(\mathrm{~A} / \mathrm{Bn}-\mathrm{cm})\end{array}$ & $\begin{array}{c}\text { Rod In } \\
k\end{array}$ & $\begin{array}{c}\text { Rod Worth } \\
(\Delta k / k)\end{array}$ \\
\hline 0 & & \\
0.0002 & 0.88742 & -0.0631 \\
0.0006 & 0.88069 & -0.0666 \\
0.002 & 0.87573 & -0.0763 \\
0.006 & 0.87144 & -0.0812 \\
2.0 & 0.87910 & -0.0725 \\
\hline
\end{tabular}

The result at a high $\mathbf{B}^{10}$ concentration is a little surprising. Adding pure absorption at any energy can only reduce multiplication. Evidently there are subtle transport effects. Epithermal effects are significant.

Information is reported here on effects from adjusting the diffusion coefficients, useful to simulate neutron streaming:

$\begin{array}{lccc}\text { Adjustment in fueled core } & \text { NO } & \text { YES } & \text { YES } \\ \text { Adjustment in non-fueled } & \text { NO } & \text { NO } & \text { YES } \\ k \text {, rods out } & 0.96012 & 0.94525 & 0.94428 \\ \Delta k / k \text {, rod insertion } & -0.0722 & -0.0726 & -0.0980\end{array}$

Thus there is but a modest effect from such a small change in the fueled core, but rather a large effect associated with changing it in the reflector. This latter effect seems to come primarily from increased transmission to the control rods. Modeling of the geometry in the vicinity of the control rods seems to be of considerable importance. 
Results for Control Rod Worth

Results obtained from three-dimensional AVR core calculations using AVR MODEL nuclide concentrations are given for reactivity worth of the four $312.4 \mathrm{~cm}$ long control rods,

Cross Section Data:
Temperature $\left({ }^{\circ} \mathrm{K}\right)$
Reference $k$
Rods Inserted, $k$
$\Delta k / k$

Cross Section Data:

$\begin{array}{ll}\text { ENDF/B-IV } \\ 400 \quad 800 \\ 1.07611 & 1.02650 \\ 0.98462 & 0.93300 \\ -0.0889 & -0.0955\end{array}$

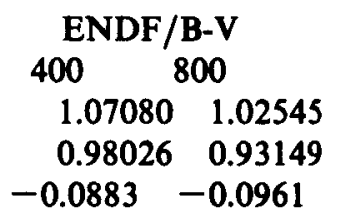

The three-dimensional control rod worth is larger than was obtained with the two-dimensional model, likely due largely to the longer length of the rods than the effective fueled bed height. The calculated result reported by AVR for a temperature of $403^{\circ} \mathrm{K}$ is -0.0906 , slightly higher than the value of -0.08873 they obtained with an earlier model. ${ }^{4}$ Values inferred from measurements are expected to be made available.

An inverse kinetics measurement of the total control rod bank worth gave $0.0819 \partial k / k$ at temperatures corresponding to full power operation, outlet coolant temperature $850^{\circ} \mathrm{C}$. A systematic inaccuracy may be the consequence of location of the flux measurement point outside of the reflector. A cold measurement of total rod bank worth by $\mathrm{N}_{2}$ replacement gave $\partial k / k$ of 0.0782 at $130^{\circ} \mathrm{C}$. The AVR staff believe inaccuracies are also associated with this method. ${ }^{10}$ The calculated values are sufficiently higher than measured worths to invite further investigation. At the least, the 4-group representation should be improved by solving the three-dimensional problem with 28-group nuclear data to improve the representation over the thermal energy range.

Values of $\mathrm{T} \partial k / k \partial \mathrm{T}$ are estimated from the above data for $600^{\circ} \mathrm{K}$,

\begin{tabular}{lrr} 
Cross Section Source & ENDF/B-IV & ENDF/B-V \\
Condition & & \\
\hline Rods Out & -0.0681 & -0.0624 \\
Rods In & -0.0777 & -0.0736
\end{tabular}

\section{ADDITIONAL REACTION RATE DATA}

Reaction rate data from three-dimensional calculations are presented here. These include data for the state with the control rods removed and also for a continuous fueling problem described below. The results shown in Table 5 are for a reference temperature of $800^{\circ} \mathrm{K}$. 
Table 5. AVR core characteristics from

three-dimensional calculations

\begin{tabular}{|c|c|c|c|}
\hline \multirow{2}{*}{$\frac{\text { Cross sections }}{\text { Nuclide data }}$} & \multirow{2}{*}{$\frac{\text { ENDF / B-IV }}{\text { AVR model }}$} & \multicolumn{2}{|c|}{ ENDF/B-V } \\
\hline & & AVR model & Calculated \\
\hline Multiplication & 1.02650 & 1.02545 & 1.0 \\
\hline \multicolumn{4}{|l|}{ Fissile conversion ratio } \\
\hline Calculated & 0.3268 & 0.3348 & 0.3859 \\
\hline Critical & $(0.3798)$ & $(0.3861)$ & - \\
\hline \multicolumn{4}{|l|}{ Peak power density $\left(w / \mathrm{cm}^{3}\right)$} \\
\hline Core & 5.616 & 5.598 & 3.882 \\
\hline Pebble & - & - & 10.30 \\
\hline \multicolumn{4}{|c|}{ Peak fast flux $\left(>8 \times 10^{5} \mathrm{eV}, \mathrm{n} / \mathrm{cm}^{2}-\mathrm{s}, \times 10^{-13}\right)$} \\
\hline Core & 5.41 & 5.40 & 6.89 \\
\hline Rad. reflector & 2.30 & 2.30 & 1.96 \\
\hline \multicolumn{4}{|l|}{ Fraction absorption } \\
\hline${ }^{232} \mathrm{Th}$ & 0.13871 & 0.14126 & 0.16160 \\
\hline${ }^{233} \mathrm{~Pa}$ & 0.00151 & 0.00153 & 0.00217 \\
\hline${ }^{233} \mathrm{U}$ & 0.09788 & 0.09835 & 0.09084 \\
\hline${ }^{234} \mathrm{U}$ & 0.00478 & 0.00513 & 0.00228 \\
\hline${ }^{235} \mathrm{U}$ & 0.39182 & 0.38824 & 0.37389 \\
\hline${ }^{236} \mathrm{U}$ & 0.00748 & 0.00756 & 0.00618 \\
\hline${ }^{238} \mathrm{U}$ & 0.01736 & 0.01747 & 0.01971 \\
\hline${ }^{239} \mathrm{Pu}$ & 0.00573 & 0.00580 & 0.01574 \\
\hline${ }^{240} \mathrm{Pu}$ & 0.00255 & 0.00257 & 0.00454 \\
\hline${ }^{241} \mathrm{Pu}$ & 0.00205 & 0.00218 & 0.00374 \\
\hline${ }^{242} \mathrm{Pu}$ & 0.00020 & 0.00023 & 0.00021 \\
\hline${ }^{243} \mathrm{Am}$ & - & - & 0.00005 \\
\hline Fission Products & 0.08378 & 0.08312 & 0.08012 \\
\hline \multicolumn{4}{|l|}{ Inventory (kg) } \\
\hline${ }^{232} \mathrm{Th}$ & 510.5 & & 550.5 \\
\hline${ }^{233} \mathrm{U}$ & 7.23 & & 6.43 \\
\hline${ }^{235} \mathrm{U}$ & 31.35 & & 27.82 \\
\hline${ }^{238} \mathrm{U}$ & 27.55 & & 31.47 \\
\hline Fissile (including ${ }^{233} \mathrm{~Pa}$ ) & 39.26 & & 35.31 \\
\hline
\end{tabular}


A three-dimensional model of continuous fueling was solved. The intent was to improve the two-dimensional results. Only ENDF/B-V cross sections were used at a reference temperature of $800^{\circ} \mathrm{K}$. The three-dimensional model explicitly represents the reflector noses into which the rods insert. Modeling of the pebble flow was somewhat poorer than was realized with the twodimensional model, however, because the volumes assigned to nuclide concentrations were not changed from what were used for the AVR MODEL. What was done in two dimensions should more accurately represent the local residence of the pebble fuel elements, although rather large zones of material were involved in the outer part of the core. In each case, the continuous fueling model involved 990 subzones of fuel material (no azmuthal variation), and the fissile feed rate was established as necessary for the core to be critical with the passage of pebble fuel elements represented explicitly. $\mathrm{Th}^{232}$ and $\mathrm{U}^{238}$ feed rates were selected for the three-dimensional case to cause the core loading of these fertile nuclides to agree with the contents reported from the FRG calculations.

The fission product poisoning is naturally of interest and just how much different it would be with the three-dimensional model. Reaction rates in the actinides are of interest. The calculated $\mathrm{U}^{235}$ feed rate of $46.4 \mathrm{grams} /$ day compares with the two-dimensional result of $47.3 \mathrm{grams} /$ day discussed earlier.

Regarding the Multiplication

The multiplication factor for the AVR core calculated with ENDF/B-V cross sections is found to be 0.025 high. Part of this may be a low estimate of the core neutron leakage through the gas

filled space above the pebble bed. Part of it may be the approximations made of the location of materials in the core. Compared with results obtained in the FRG, the current estimate of fission product absorptions seems to be low. ENDF data was not used for this. Some local study should be done to clarify the situation.

\section{ACKNOWLEDGEMENTS}

This effort was especially useful due to contributions from the staff at the AVR and the KFA in the FRG. Acknowledgement is made of contributions made by J. C. Cleveland in reviewing the report on this work. The manuscript was prepared by Stephanie Raby and Anita Weil.

\section{REFERENCES}

1. W. E. Ford, et al., "CSRL-V: Processed ENDF/B-V 227-Neutron Group and Pointwise Cross-Section Libraries for Criticality Safety, Reactor and Shielding Studies," NUREG/CR-2306, ORNL/CSD/T-160, June 1982.

2. W. E. Ford, III, et al., "A 218-Group Neutron Cross-Section Library in the AMPX Master Interface Format for Criticality Safety Studies," ORNL/CSD/TM-4, July 1976.

3. K. J. Krüger, Data transmission from AVR to J. C. Cleveland, ORNL, May 1985. 
4. R. Wagemann et. al., "Arbeitsgemeinschaft Versuchs-Reaktor AVR: Zusammenstellung, der Reaktorphysikalischen Daten, des AVR-Atomversuchskraftwerks fur das Jahr 1981", Gesellschaft mit beschräukter Haftung, Dusseldorf /FRG; AVR, Hauptabteilung T1 (1981).

5. D. R. Vondy, T. B. Fowler, and G. W. Cunningham, III, "Exploiting the Steady State, Continuous Fueling Reactor Model," ANS Williamsburg M\&CD Topical Meeting, April 1979; Proc. Vol. 3, p. 11 (1979).

6. D. R. Vondy, T. B. Fowler, and G. W. Cunningham, III, "VENTURE: A Code Block for Solving Multigroup Neutronics Problems Applying the Finite-Difference Diffusion-Theory Approximation to Neutron Transport, Version II," ORNL-5062/R1, November 1977.

7. D. R. Vondy, T. B. Fowler, and G. W. Cunningham, III, "The Bold Venture Computation System for Nuclear Reactor Core Analysis, Version III," ORNL-5711, June 1981.

8. D. R. Vondy, "PEBBLE: A Two-Dimensional Steady-State Pebble Bed Reactor Thermal Hydraulics Code," ORNL-5698, September 1981.

9. N. M. Green, et al., "AMPX: A Modular Code System for Generating Coupled Multigroup Neutron-Gamma Libraries from ENDF/B," ORNL/TM-3706, March 1976.

10. P. Pohl, (AVR) Conversation with J. C. Cleveland Regarding AVR Control Rod Worth Measurements," May 1986. 


\section{APPENDIX}

\section{METHODS}

The AVR core calculations were done applying diffusion theory using 4-group cross sections. The VENTURE ${ }^{6}$ neutronics and associated codes $^{7,8}$ were used. Results produced with these methods are reported directly.

The steady-state condition associated with continuous fueling with pebble feed, recycle, and discharge is modeled directly to obtain a solution iteratively to establish the necessary core conditions and the feed composition. Since a global iteration process is used, the results are converged only to a reasonable degree of accuracy. Representative paths of the pebbles are followed and the increase in the residence time with increase in the radial location was modeled. Early models that were tested proved somewhat inadequate. The 100 core regions were subdivided into 990 locations treated explicitly for exposure but homogenized to the 100 locations for the neutronics calculation. The fuel pebble management was assumed to be discharge of 600 pebbles/day and makeup of 60 pebbles/day fresh fuel. A core residence time of 1,585 days was used. The modeling was somewhat complicated with variation in residence time and no fresh fuel elements fed to the central port. The thermal hydraulics calculation treats 990 pebble fuel elements for reference conditions in this model (instead of one for each zone), and then treats these again for zone extreme conditions. Additional effort would likely improve the modeling of the core, its contents, and the representation of the fuel element traverses.

\section{NUCLEAR DATA}

Nuclear data in multigroup form from ENDF/B- $V^{1}$ was used for the nuclides shown in Table $A$. Revised ${ }^{232} \mathrm{Th}$ and graphite data has replaced the original. The ENDF/B-V data were used from a 28-group library collapsed from the original 228-group set of data. These data were supplemented with data from a 123-group library in local use as indicated in the table, making up a set useful for core analysis, generally not ENDF data. Also, data available were used from ENDF/B-IV, ${ }^{2}$ substituted as shown. A 27-group set of ENDF/B-IV cross sections were available that were collapsed from an original 218-group structure. Revised ENDF/B-IV graphite data is in use. Emphasis was placed on the actinides. Local processing of fission product point data is incomplete and under further study. Much resonance data is involved impacting application since shielding changes with exposure.

The cases only reconstruct the German fission product inventory in part, so some differences will result here. The properties of a pseudo lumped fission product in use at ORNL were used for the German data that actually should be different. A small amount of $1 / \mathrm{v}$ absorber was included to represent impurities in the graphite. (Nuclides ${ }^{135} \mathrm{I}$ and ${ }^{147} \mathrm{Nd}$ identify pseudo data in common local use to allow slow transients to be followed). 
Table A. Nuclear data source for nuclides

\begin{tabular}{|c|c|c|c|c|}
\hline Number & Nuclide & $\begin{array}{c}\text { ENDF/B-V } \\
\text { (basis) }\end{array}$ & $\begin{array}{c}\text { Supplemented } \\
\text { (123 group } \\
\text { library) }\end{array}$ & $\begin{array}{c}\text { ENDF/B-IV } \\
\text { (replaced) }\end{array}$ \\
\hline 1 & ${ }^{232} \mathrm{Th}$ & $\mathbf{x}$ & & $\mathbf{x}$ \\
\hline 2 & ${ }^{233} \mathrm{~Pa}$ & $\mathrm{x}$ & & $\mathbf{x}$ \\
\hline 3 & ${ }^{233} \mathrm{U}$ & $\mathbf{x}$ & & $\mathbf{x}$ \\
\hline 4 & ${ }^{234} \mathrm{U}$ & $\mathrm{x}$ & & $\mathbf{x}$ \\
\hline 5 & ${ }^{235} \mathrm{U}$ & $\mathrm{x}$ & & $\mathbf{x}$ \\
\hline 6 & ${ }^{236} \mathrm{U}$ & $\mathbf{x}$ & & $\mathbf{x}$ \\
\hline 7 & ${ }^{238} \mathrm{U}$ & $\mathrm{x}$ & & $\mathrm{x}$ \\
\hline 8 & ${ }^{237} \mathrm{~Np}$ & $\mathbf{x}$ & & $\mathbf{x}$ \\
\hline 9 & ${ }^{239} \mathrm{~Np}$ & & $\mathbf{x}$ & \\
\hline 10 & ${ }^{239} \mathrm{Pu}$ & $\mathbf{x}$ & & $\mathbf{x}$ \\
\hline 11 & ${ }^{240} \mathrm{Pu}$ & $x$ & & $\mathbf{x}$ \\
\hline 12 & ${ }^{241} \mathrm{Pu}$ & $\mathbf{x}$ & & $\mathbf{x}$ \\
\hline 13 & ${ }^{242} \mathrm{Pu}$ & $x$ & & $\mathrm{x}$ \\
\hline 14 & ${ }^{243} \mathrm{Am}$ & $x$ & & \\
\hline 15 & ${ }^{82} \mathrm{Kr}$ & $\mathbf{x}$ & & \\
\hline 16 & ${ }^{83} \mathrm{Kr}$ & $\mathbf{x}$ & & \\
\hline 17 & ${ }^{103} \mathrm{Rh}$ & $\mathbf{x}$ & & \\
\hline 18 & ${ }^{105} \mathbf{R h}$ & & $\mathrm{x}$ & \\
\hline 19 & ${ }^{109} \mathrm{Ag}$ & $\mathrm{x}$ & & $\mathbf{x}$ \\
\hline 20 & ${ }^{135} \mathrm{I}$ & & $\mathbf{x}$ & \\
\hline 21 & ${ }^{131} \mathrm{Xe}$ & $\mathbf{x}$ & & \\
\hline 22 & ${ }^{133} \mathrm{Xe}$ & & $\mathbf{x}$ & \\
\hline 23 & ${ }^{135} \mathrm{Xe}$ & $x$ & & \\
\hline 24 & ${ }^{133} \mathrm{Cs}$ & $x$ & & \\
\hline 25 & ${ }^{134} \mathrm{Cs}$ & & $\mathrm{x}$ & \\
\hline 26 & ${ }^{135} \mathrm{Cs}$ & & $\mathbf{x}$ & \\
\hline 27 & ${ }^{143} \mathrm{Nd}$ & & $\mathbf{x}$ & \\
\hline 28 & ${ }^{145} \mathrm{Nd}$ & & $\mathbf{X}$ & \\
\hline 29 & ${ }^{147} \mathrm{Nd}$ & & $\mathbf{x}$ & \\
\hline 30 & ${ }^{147} \mathrm{Pm}$ & & $\mathbf{x}$ & \\
\hline 31 & ${ }^{148} \mathrm{Pm}$ & & $\mathrm{X}$ & \\
\hline 32 & ${ }^{148 m} \mathrm{Pm}$ & & $\mathbf{X}$ & \\
\hline 33 & ${ }^{149} \mathrm{Pm}$ & & $\mathbf{x}$ & \\
\hline 34 & ${ }^{149} \mathrm{Sm}$ & $\mathbf{x}$ & & \\
\hline 35 & ${ }^{150} \mathrm{Sm}$ & & $x$ & \\
\hline 36 & ${ }^{151} \mathrm{Sm}$ & & $\mathbf{x}$ & \\
\hline 37 & ${ }^{152} \mathrm{Sm}$ & & $x$ & \\
\hline 38 & ${ }^{133} \mathrm{Eu}$ & $\mathbf{x}$ & & \\
\hline 39 & ${ }^{154} \mathrm{Eu}$ & $x$ & & \\
\hline 40 & ${ }^{155} \mathrm{Eu}$ & & $x$ & \\
\hline 41 & FP1 & & $\mathbf{x}$ & \\
\hline 42 & FP2 & & $\mathrm{x}$ & \\
\hline 43 & C & $\mathrm{X}$ & & $\mathrm{x}$ \\
\hline 44 & $C(R)$ & $\mathrm{x}$ & & $x$ \\
\hline 45 & 0 & $\mathbf{x}$ & & $\mathrm{x}$ \\
\hline 46 & $\mathrm{He}$ & $\mathrm{x}$ & & $x$ \\
\hline 47 & ${ }^{10} \mathrm{~B}$ & $\mathrm{x}$ & & $x$ \\
\hline 48 & $1 / v$ & $x$ & & $x$ \\
\hline
\end{tabular}




\section{CROSS SECTION PROCESSING}

Resonance shielding was done with a single resonance model $^{9}$ at the fuel kernel level applying a Dancoff factor of 0.40 to account for the environment. A one-dimensional discrete ordinates ${ }^{9}$ cell calculation was done for the fuel element $(2.5-\mathrm{cm}$ radius fueled sphere inside) in the group structure of the data. The results were weighted with the cell neutron flux to produce effective cross sections ( 27 or 28 group). Then a one-dimensional discrete ordinates ${ }^{9}$ core traverse was done and the data were then collapsed with the flux to generate 4-group data subsequently used with diffusion theory.

Note that calculations treating the fuel cell and one or more core dimensions could be done in a finer group structure, as in 227 groups for the processed ENDF/B-V data. This was not done, so we refer to earlier work where more elaborate representation was done for comparison. Nor were multidimensional calculations done treating more than four groups.

\section{MODELING}

The diffusion coefficients in the core were increased by 0.01 to approximate the effect of neutron streaming. A maximum value of the diffusion coefficient allowed was $60 \mathrm{~cm}^{-1}$. It should be noted that the modeling used for calculating the temperature coefficient of reactivity involved a discrete temperature change over the whole core. (What happens with a power level change or upon reactivity addition is somewhat more complicated.) Temperature variation over the reactor core was not considered in these early calculations. (Holding the reflector at $600^{\circ} \mathrm{K}$ causes the results to be incomplete in regard to the total defect, for example.)

A noteworthy limitation in the modeling is the thermal hydraulics application, The pebbles piled at the top of the bed and the conical core bottom were only crudely modeled. Excessive fuel temperature peaking may result from the approximation that is a distortion. Also, the presence of the control rod holder nose pieces was ignored, increasing the cross sectional area as handled. Whereas with the continuous fueling model the fluence was calculated for correlating the thermal conductivity in the fuel element pebbles, a rather high number of $2.5 \times 10^{21} \mathrm{n} / \mathrm{cm}^{2}>1.85 \times 10^{5} \mathrm{eV}$ was used for the other models. Further effort would be required to assess the situation if results of a high quality are needed; indeed some methods improvement is desirable and might be found to be essential.

In some cases equilibrium ${ }^{135} \mathrm{Xe}$ was calculated when the diffusion theory neutronics problem was solved. This was done on a region-average basis applying an average total fission yield fraction. 
ORNL/TM-10056

Distribution Category UC-77T

\section{INTERNAL DISTRIBUTION}

$\begin{aligned} 1-2 . & \text { L. S. Abbott } \\ 3 . & \text { D. G. Cacuci } \\ 4 . & \text { J. C. Cleveland } \\ 5-7 . & \text { P. R. Kasten } \\ 8 . & \text { F. C. Maienschein } \\ 9 . & \text { D. L. Moses } \\ 10 . & \text { P. L. Rittenhouse } \\ 11 . & \text { R. T. Santoro } \\ 12-15 . & \text { D. R. Vondy } \\ 16 . & \text { R. M. Westfall } \\ 17 . & \text { B. A. Worley }\end{aligned}$

\author{
18. A. Zucker \\ 19. P. W. Dickson, Jr. (Consultant) \\ 20. G. H. Golub (Consultant) \\ 21. R. M. Haralick (Consultant) \\ 22. D. Steiner (Consultant) \\ 23-24. Central Research Library \\ 25. Y-12 Document Ref. Section \\ 26-27. Laboratory Records Department \\ 28. Laboratory Records ORNL, RC \\ 29. ORNL Patent Office \\ 30. EPIC \\ 31. EPMD Reports Office
}

\section{EXTERNAL DISTRIBUTION}

32. A. C. Millunzi, Acting Director, Division of HTGRs, DOE, NE-531, Washington, D.C. 20545

33. Office of Assistant Manager for Energy Research and Development, Oak Ridge Operations Office, DOE, P.O. Box E, Oak Ridge, TN 37831

34. DOE, Director, Office of Advanced Reactor Programs, NE-53, Washington, D.C. 20545

35. L. Lanni, DOE-SAN, 1333 Broadway, Oakland, CA 94612

36. F. Sims, DOE, Idaho Operations Office, 550 2nd St., Idaho Falls, ID 83401

37. J. E. Fox, Division of HTGRs, DOE, NE-531, Washington, D.C. 20545

38. A. S. Mehner, Division of HTGRs, DOE, NE-531, Washington, D.C. 20545

39. G. Baccaglini, GA Technologies Incorporated, P.O. Box 85608, San Diego, CA 92138

40. A. M. Baxter, GA Technologies Incorporated, P.O. Box 85608, San Diego, CA 92138

41. S. J. Brown, GA Technologies Incorporated, P.O. Box 85608,San Diego, CA 92138

42. S. A. Caspersson, Combustion Engineering, Inc., 1000 Prospect Hill Road, Windsor, CT 06095

43. C. Cowan, General Electric, P.O. Box 3508, Sunnyvale, CA 94088

44. D. D. DeFur, Combustion Engineering, Inc., 911 West Main Street, Chattanooga, TN 37402

45. S. Golan, Bechtel National, Inc., P.O. Box 3965, San Francisco, CA 94119

46. G. Jones, Gas-Cooled Reactor Associates, 10240 Sorrento Valley Road, Suite 300, San Diego, CA 92121

47. L. D. Mears, General Manager, Gas-Cooled Reactor Associates, Suite 300, 10240 Sorrento Valley Road, San Diego, CA 92121

48. A. J. Neylan, Director, DOE Projects, GA Technologies Incorporated, P.O. Box 85608, San Diego, CA 92138

49. J. E. Quinn, General Electric Company, P.O. Box 3508, Sunnyvale, CA 94088

50. W. R. Sheridan, Stone and Webster Engineering Corporation, P.O. Box 2325, Boston, MA 02107

51. C. L. Storrs, Director, Advanced Development, Combustion Engineering, Inc., 1000 Prospect Road, Windsor, CT 06095

52. R. F. Turner, GA Technologies Incorporated, P.O. Box 85608, San Diego, CA 92138

53-54. K. Krueger, AVR-GnbH, D-5170, Jülich, Federal Republic of Germany

55-56. E. Teuchert, Institute fur Reacktorentwicklung, Kernforchungsanlage, D-5170 Jülich, Federal Republic of Germany

57-115. For distribution as shown in TID-4500, Distribution Category UC-77T (Gas Cooled Reactor Technology) 